\title{
PERAN KEPERCAYAAN MEMEDIASI PERSEPSI RISIKO TERHADAP NIAT MENGGUNAKAN MANDIRI MOBILE BANKING DI KOTA DENPASAR
}

\author{
Ida Ayu Agung Upadianti Jayantari ${ }^{1}$ \\ Ni Ketut Seminari² \\ ${ }^{1,2}$ Fakultas Ekonomi dan Bisnis Universitas Udayana (Unud), Bali, Indonesia \\ e-mail : dayu.agung@yahoo.com
}

\begin{abstract}
ABSTRAK
Persepsi risiko merupakan faktor yang berpengaruh dalam adanya niat seseorang untuk menggunakan suatu produk. Perusahaan harus memperhatikan faktor faktor yang dapat memperkecil persepsi risiko tersebut, salah satunya adalah kepercayaan. Penelitian ini ingin menjelaskan peran kepercayaan dalam memediasi persepsi risiko terhadap niat menggunakan. Penelitian ini dilakukan di Kota Denpasar dengan melibatkan 100 responden. Metode pengumpulan data yang digunakan yaitu purposive sampling. Pengumpulan data dilakukan dengan menyebarkan kuesioner. Selanjutnya, data dari hasil pengumpulan kuesioner diolah dengan menggunakan uji validitas, dan uji reliabilitas untuk mengetahui kelayakan dan konsistensi indikator dalam kuesioner tersebut. Selain itu, dilakukan uji lain yaitu analisis jalur (path analysis) dan Teori Solimun. Hasil penelitian ditemukan bahwa persepsi risiko berpengaruh negatif dan signifikan terhadap niat menggunakan. Sementara kepercayaan berpengaruh positif dan signifikan terhadap niat menggunakan. Sehingga dapat dikatakan bahwa untuk meningkatkan niat menggunakan dapat dilakukan dengan meminimalisasi persepsi risiko dan menumbuhkan kepercayaan.
\end{abstract}

Kata kunci: persepsi risiko, kepercayaan, niat menggunakan

\begin{abstract}
Risk perception is an influential factor in a person's intention to use a product. Companies should consider factors that can minimize the perception of these risks, one of which is trust. This study wishes to explain the role of confidence in mediating the perception of risk to the intent of using. This research was conducted in Denpasar City involving 100 respondents. Data collection method used is purposive sampling. Data collection was done by distributing questionnaires. Furthermore, data from the results of collecting questionnaires processed by using the validity test, and reliability test to determine the feasibility and consistency of indicators in the questionnaire. In addition, another test is conducted path analysis (path analysis) and Solimun Theory. The results of the study found that the perception of risk had a negative and significant effect on the intention of using. While trust has a positive and significant effect on the intention of using. So it can be said that to increase the intention of using can be done by minimizing risk perception and foster trust.
\end{abstract}

Keywords: risk perception, trust, intention to use. 
Ida Ayu Agung Upadianti Jayantari, Peran Kepercayaan Memediasi...

\section{PENDAHULUAN}

Kemajuan teknologi informasi dapat dilihat dari perkembangan internet di seluruh belahan dunia. Masyarakat saat ini cenderung menggunakan perangkat mobile untuk menunjang keperluannya, seperti melakukan transaksi pembelian atau pembayaran dan mencari informasi produk (Thakur et al., 2012). Survei yang dilakukan oleh Asosiasi Penyelenggara Jaringan Internet Indonesia (APJII) pada tahun 2016 mengungkap bahwa lebih dari setengah penduduk Indonesia kini telah terhubung ke internet (apjii.or.id).

Fenomena ini dimanfaatkan oleh perbankan untuk membuat fasilitas yang memudahkan para nasabahnya dalam bertransasksi dimanapun mereka berada melalui Electronic Banking atau disingkat E-Banking (Vebrika, 2007). Elektronic Banking adalah jasa bank yang memungkinkan nasabah untuk memperoleh informasi, melakukan komunikasi dan transaksi perbankan melalui jaringan internet (Tampubolon, 2004:134). Di dalam E-Banking juga terdapat beberapa aspek seperti internet banking, mobile banking dan sms banking. Survei yang dilakukan APJII juga mengungkap bahwa rata-rata pengakses internet di Indonesia menggunakan perangkat genggam. Berdasarkan perangkat yang digunakan, penggunaan mobile phone menempati urutan pertama dengan 50,7\% atau sekitar 67,2 juta penduduk (apjii.or.id). Hasil survei yang dikutip dari website sharingvision.com menyatakan bahwa persentase jumlah pengguna mobile banking lebih besar dibandingkan dengan yang tidak menggunakannya. Kebutuhan informasi yang dapat dipenuhi oleh mobile banking ini tentunya terkait 
pula dengan transaksi online yang menunjukkan trend yang meningkat (Ichwan,2014).

Di Indonesia sendiri, perkembangan mobile banking dimulai sejak tahun 1998. Namun, layanan tersebut masih dalam tahap percobaan dan belum bisa maksimal. Baru di tahun 2000, implementasi penggunaan mobile banking mulai banyak diterapkan oleh bank-bank di Indonesia. Berikut adalah urutan bank penyedia layanan mobile banking di Indonesia :

Tabel 1.

Bank Penyedia LayananMobile Banking di Indonesia

\begin{tabular}{ccl}
\hline No & Tahun & \multicolumn{1}{c}{ Bank } \\
\hline 1. & 1998 & Bank Internasional Indonesia \\
2. & 2000 & Bank Niaga \\
3. & 2001 & Bank Bukopin \\
4. & 2001 & Bank Central Asia \\
5. & 2003 & Bank Mandiri \\
6. & 2005 & Bank PermataNet \\
7. & 2006 & Bank Permata Bussiness \\
8. & 2007 & Bank Negara Indonesia, Bank Lippo \\
9. & 2008 & Bank Danamon \\
10. & 2009 & Bank Rakyat Indonesia \\
11. & 2010 & Bank Mega \\
\multicolumn{3}{l}{ Sumber: Wikipedia.com, 2017 }
\end{tabular}

Dari Tabel 1. dapat dilihat salah satu perbankan yang menyediakan fasilitas layanan mobile banking adalah Bank Mandiri. Sebagai bank BUMN di Indonesia, Bank Mandiri sudah memanfaatkan teknologi informasi ke dalam layanan mobile banking sejak tahun 2003. Berdasarkan survei yang dilakukan oleh Marketing Research Indonesia (MRI), Bank Mandiri berhasil meraih predikat bank terbaik dalam segi pelayanan selama empat tahun berturut-turut periode 2013-2016 (vivanews.com). Dalam penghargaan ini, salah satu kriteria penilaiannya adalah pelayanan mobile banking. Bank Mandiri juga mendapat tempat pertama dalam 
Ida Ayu Agung Upadianti Jayantari, Peran Kepercayaan Memediasi...

penghargaan kategori pelayanan Internet Banking, Mobile Banking serta Customer Service pada tahun 2016 (bankmandiri.com)

Melalui layanan Mobile Banking, memeriksa saldo rekening, memonitor jangka waktu deposito, mengecek kartu kredit serta pembayaran lain dan transaksi lainnya akan lebih mudah dilakukan. Namun, walaupun tingkat penggunaan mobile banking sudah terbilang tinggi, namun ada pula faktor yang dapat membuat konsumen ragu dalam menggunakan mobile banking, salah satunya adalah faktor persepsi risiko (Pratiwi, 2012). Risiko dianggap sebagai kejadian yang konotasinya merugikan atau negatif(Hanafi, 2009:17). Risiko muncul karena minimnya interaksi langsung antara pengguna dengan teller di bank yang bersangkutan. Sehingga memunculkan keraguan konsumen dalam melaksanakan transaksi tersebut. Persepsi risiko merupakan hal yang mengganjal di pikiran konsumen karena banyaknya kemungkinan yang tidak dapat dipastikan (Samadi et al.,2009). Risiko dianggap sebagai penghalang bagi konsumen yang sedang mempertimbangkan apakah akan melakukan transaksi secara online atau tidak (Pavlou, 2006). .

Persepsi risiko merupakan faktor yang memiliki peran penting dalam membentuk minat individu untuk menggunakan e-Commerce (Suhir dkk.,2014).Persepsi risiko juga memiliki pengaruh yang signifikan terhadap niat menggunakan e-commmerce (Nazar dkk.,2008). Persepsi risiko ini mempunyai dampak negatif terhadap niat digunakannya e-commerce dan memiliki pengaruh yang kuat pada minat beli yang berujung pada keputusan pembelian yang dibuat oleh konsumen. (Kim et al., 2008). Namun hasil ini tidak konsisten dengan 
penelitian yang dilakukan oleh Novitasari dkk, (2015) yang menyebutkan bahwa tidak adanya pengaruh yang signifikan antara persepsi risiko terhadap niat untuk bertransaksi secara online. Hasil serupa diungkapkan oleh Rahayu (2012) yang menyebutkan pada hasil penelitiannya bahwa persepsi risiko tidak berpengaruh secara signifikan pada niat beli konsumen. Gurung (2006) juga menyatakan persepsi resiko tidak berpengaruh terhadap niat pembelian melalui sistem $e$ commerce. Penelitian yang dilakukan menunjukkan tidak ada dukungan untuk argumen yang menyatakan bahwa semakin tinggi persepsi resiko menyebabkan niat yang kecil untuk melakukan transaksi dalam sistem e-commerce.

Selain itu, persepsi risiko juga berpengaruh terhadap kepercayaan. Penelitian yang dilakukan oleh Rong et al. (2007) menyatakan bahwa persepsi risiko memiliki pengaruh negatif terhadap kepercayaan konsumen dalam transaksi online. Rendahnya kepercayaan konsumen akan berpengaruh terhadap keputusan penggunaan produk tersebut. Penelitian yang dilakukan Firdayanti (2012) juga mengemukakan hal yang sama. Persepsi risiko secara langsung mempengaruhi kepercayaan konsumen, jika persepsi risiko tinggi maka terjadi distrust atau ketidakpercayaan yang mengakibatkan keragu-raguan dan kemungkinan untuk meninggalkan OnlineStore atau transaksi, dan jika persepsi risiko rendah maka akan terjadi trust yang selanjutnya berefek pada komitmen serta kesetiaan pelanggan.

Hal lain yang juga sangat mempengaruhi konsumen dalam menarik niat menggunakanadalah kepercayaan. Dikutip dari dailysosial.com menyatakan bahwa penghalang terbesar penggunaan mobile banking untuk transaksi finansial 
Ida Ayu Agung Upadianti Jayantari, Peran Kepercayaan Memediasi...

adalah masalah kepercayaan. Semakin tinggi kepercayaan konsumen, keputusan untuk melakukan suatu pembelian terhadap suatu produk akan meningkat (Murwatiningsih dkk, 2013). Penelitian mengenai pengaruh kepercayaan juga pernah dilakukann oleh Anwar dkk.(2016). Penelitian tersebut mengemukakan bahwa kepercayaan berpengaruh positif terhadap niat bertransaksi secara online.

Sebanyak $32 \%$ pengguna mobile di Indonesia menyebutkan bahwakepercayan sebagai masalah utama yang membuatnya khawatir menggunakan transaksi online (dailysocial.com). Niat itu sendiri merupakan gabungan dari kepercayaan dan sikap konsumen terhadap produk dan jasa. Jaafar et al., (2012) mengungkapkan biasanya niat konsumen untuk membeli maupun menggunakan suatu produk terkait dengan perilaku konsumen, persepsi dan sikap mereka.

Berdasarkan hasil data diatas, dapat dilihat bahwa kepercayaan dan persepsi risiko masih menjadi masalah yang sangat mempengaruhi niat konsumen dalam menggunakan mobile banking. Perusahaan perbankan yang menyediakan layanan berbasis mobile banking harus lebih jeli dalam memperhatikan faktor faktor yang dapat menunjang kepercayaan. Kim et al., (2008) mengungkapkan bahwa untuk meningkatkan niat konsumen menggunakan produk yang disediakan oleh suatu perusahaan, perusahaan harus mampu meningkatkan aspek kepercayaan konsumen serta mengimbanginya dengan menurunkan risiko yang mungkin diterima konsumen. Maka, untuk membuktikan hal ini diperlukan suatu penelitian lebih lanjut menggunakan variabel tersebut. Penelitian ini diharapkan dapat menjawab semua permasalahan dan hipotesis yang disusun. 
Berdasarkan latar belakang yang telah dijabarkan, adapun tujuan dari penelitian ini adalah untuk menjelaskan pengaruh persepsi risiko terhadap niat konsumen menggunakan Mandiri mobile banking, untuk menjelaskan pengaruh persepsi risiko terhadap kepercayaan konsumen pada produk Mandiri mobile banking, untuk menjelaskan pengaruh kepercayaanterhadap niat konsumen menggunakan Mandirimobile banking dan untuk mengetahui peran kepercayaan dalam memediasi persepsi risiko konsumen dengan niat konsumen menggunakan Mandiri mobile banking.

Penelitian ini memiliki dua manfaat, yaitu manfaat teoritis dan maanfaat praktis. Manfaat teoritis dalam penelitan ini berupa penelitian ini diharapkan memberikan dan dapat menambah bukti empiris tentang studi mengenai persepsi risiko, kepercayaan, dan niat menggunakan. Penelitian ini juga diharapkan untuk mampu memberikan acuan dan menjadi referensi bagi penelitian-penelitian selanjutnya di bidang yang terkait dengan penelitian ini. Manfaat praktis berupa hasil penelitian ini diharapkan dapat menjadi bahan pertimbangan pengambilan keputusan bagi Bank Mandiri dalam pelayanan mobile banking untuk dapat menurunkan persepsi risiko dan meningkatkan kepercayaan, serta niat calon konsumen untuk menggunakan produk yang ditawarkan, sehingga mampu memberikan hasil yang lebih baik pada perusahaan

Persepsi risiko didefinisikan sebagai perkiraan subjektif individu untuk mendapatkan konsekuensi kerugian dalam menerima suatu hasil yang diinginkannya (Pavlou, 2001). Selain itu, risiko merupakan faktor pendahulu yang memperoleh kepercayaan (Gefen et al., 2003). Pendapat lain diutarakan oleh 
Ida Ayu Agung Upadianti Jayantari, Peran Kepercayaan Memediasi...

Hartono (2012:63) yang mendefinisikan persepsi risiko sebagai suatu persepsipersepsi pelanggan tentang ketidakpastian dan konsekuensi-konsekuensi tidak diinginkan dalam melakukan suatu kegiatan. Berdasarkan beberapa definisi risiko tersebut, maka yang dimaksud risiko adalah penilaian subjektif oleh seseorang terhadap kemungkinan dari sebuah kejadian kecelakaan dan seberapa khawatir individu dengan konsekuensi atau dampak yang ditimbulkan kejadian tersebut.

Menurut Pavlou dan Fygenson (2006), persepsi resiko diukur dengan indikator sebagai berikut: Risiko finansial yang berkaitan dengan jumlah biaya yang dilakukan saat bertransaksi menggunakan mobile banking, risiko keamanan yang berkaitan dengan keamanan data dan informasi-informasi yang terdapat di dalam mobile banking dan risiko produk yang berkaitan dengan teknik-teknik penggunaan serta kehandalan mobile banking sebagai salah satu media transaksi online.

Salah satu hal yang berpengaruh dalam keputusan konsumen untuk menggunakan produk jasa berbasis online adalah suatu kepercayaan. Kepercayaan adalah kecenderungan satu pihak yang bersedia untuk dapat menerima keputusan dari pihak lain(Ling et al., 2011). Gefen dan Straub (2004) dalam Ling et al.,(2010). menyimpulkan bahwa semakin tinggi tingkat kepercayaan konsumen, maka semakin tinggi pula niat menggunakan konsumen tersebut. Kepercayaan merupakan suatu level dimana keinginan untuk membeli produk tergantung pada ekspektasi pada kemampuan, reabilitas, dan kebaikan dari produk tersebut (Chen, 2012). 
Ago et al, (2015) menyatakan kepercayaan konsumen pada produk yakni bahwa produk tersebut memiliki atribut dan hal ini diakibatkan oleh pengetahuan konsumen. Kepercayaan konsumen (consumer beliefs) adalah segala pengetahuan yang dimiliki oleh konsumen dan kesimpulan yang dibuat konsumen tentang objek, atribut, dan manfaatnya (Mowen dan Minor, 2002:312). Kepercayaan ini juga dikatakan sebagai suatu kekuatan yang mengikat dalam kebanyakan transaksi antara pembeli dengan penjual (Chong et al., 2003). Menurut Afzal et al. (2010) kepercayaan berarti harapan dari orang lain pada tugas tertentu, dan harapan bervariasi antara skala rating tinggi dan rendah.

Kepercayaan konsumen dapat dikatakan sebagai harapan konsumen bahwa penyedia jasa dapat dipercaya atau diandalkan dalam memenuhi janjinya (Siagian dkk., 2014). Kepercayaan ini juga dikatakan dapat meningkatkan keinginan mulai menggunakan atau proses penggunaan secara berkelanjutan bagi calon pelanggan maupun pelanggan (Rizanata, 2014). Terdapat empat indikator yang dapat membentuk kepercayaan seseorang menurut Chen dan Chang (2012) yakni : Kepercayaan akan reputasi yang baik, kepercayaan mengenai kehandalan kinerja, kepercayaan akan keamanan bertransaksi dan kepercayaan akan tidak bertindak secara illegal.

Keputusan konsumen untuk membeli maupun menggunakan suatu produk dapat dikatakan sangat kompleks dan sebelum keputusan itu dibuat tentu diawali dengan niat yang merupakan tendensi seseorang ketika orang tersebut berusaha untuk menggunakan sikap secara spesifik (Warmanto dan Thenu, 2009). Niat merupakan gabungan dari kepercayaan dan sikap konsumen terhadap produk dan 
Ida Ayu Agung Upadianti Jayantari, Peran Kepercayaan Memediasi...

jasa. Biasanya niat konsumen untuk membeli maupun menggunakan suatu produk terkait dengan perilaku konsumen, persepsi dan sikap mereka (Jaafar et al.,2012). Niat juga dikatakan merupakan tahap kecenderungan responden untuk bertindak sebelum benar-benar melakukan pembelian (Martinez dan Kim, 2012). Niat beli atau menggunakan mengacu pada evaluasi atau sikap konsumen terhadap produkproduk terkait, dengan rangsangan dari faktor eksternal sehingga konsumen bersedia untuk membeli produk yang ditawarkan(Sujana, 2016). Niat menggunakanmerupakan suatu keinginan seseorang untuk menggunakan merek atau produk tertentu yang telah mereka pilih untuk diri mereka sendiri setelah adanya proses evaluasi(Rizanata, 2014).

Niat konsumen untuk menggunakan suatu produk dikatakan dapat diukur. Ferdinand (2002:129) memaparkan bahwa niat konsumen untuk menggunakan suatu produk tersebut dapat diukur melalui beberapa indikator yakni sebagai berikut: Niat Transaksional, yakni kecenderungan seseorang untuk membeli produk. Niat Refrensial, yakni kecenderungan seseorang untuk mereferensikan produk kepada orang lain. Niat Preferensial, yakni menggambarkan perilaku seseorang yang memiliki prefrensi utama pada produk tersebut. Niat Eksploratif, menggambarkan perilaku seseorang yang selalu mencari informasi mengenai produk yang diminatinya dan mencari informasi untuk mendukung sifat-sifat positif dari produk tersebut.

Penelitian yang dilakukan oleh Nazar dan Syahra (2008), Suhir (2014), Eastlick et al., (2006), Firdayanti (2012) dan Benaditta (2012) menemukan bahwa terdapat pengaruh yang negatif dan signifikan antara persepsi risiko terhadap 
kepercayaan untuk bertransaksi secara online, semakin tinggi persepsi risiko konsumen, maka tingkat kepercayaan konsumen akan semakin menurun. Berdasarkan hasil empiris pada penelitian di atas, hipotesis yang dapat diajukan dalam penelitian ini adalah:

$\mathrm{H}_{1} \quad$ : Persepsi risiko memiliki pengaruh negatif dan signifikan terhadap kepercayaan konsumen.

Penelitian oleh Dewi (2016), Kim et al. (2008), dan Martinayanti (2016) menemukan bahwa terdapat pengaruh negative antara hubungan persepsi risiko terhadap niat seseorang untuk menggunakan ataupun membeli sesuatu. Berdasarkan hasil empiris pada penelitian di atas, hipotesis yang dapat diajukan dalam penelitian ini adalah:

$\mathrm{H}_{2}$ : Persepsi risiko memiliki pengaruh negatif dan signifikan terhadap niat menggunakan Mandiri mobile banking.

Penelitian yang dilakukan oleh Kamtarin (2012), Adji dan Semuel (2014), Nusarika (2015) dan Sujana (2016), diketahui bahwa kepercayaan konsumen berpengaruh positif dan signifikan terhadap niat beli konsumen, artinya jika kepercayaan yang dimiliki konsumen akan suatu produk semakin tinggi maka akan semakin tinggi pula niat konsumen untuk menggunakan atau membeli produk tersebut. Berdasarkan hasil empiris pada penelitian di atas, hipotesis yang dapat diajukan dalam penelitian ini adalah:

$\mathrm{H}_{3}$ : Kepercayaan konsumen memiliki pengaruh positif dan signifikan terhadap niat menggunakan Mandirimobile banking 
Ida Ayu Agung Upadianti Jayantari, Peran Kepercayaan Memediasi...

Penelitian oleh Wu et al. (2014), Chen (2012), Ling et al. (2011), Murwatiningsih dkk. (2013) dan Martinayanti (2016) diketahui bahwa adanya hubungan mediasi kepercayaan terhadap persepsi risiko dan niat beli. Berdasarkan hasil empiris pada penelitian di atas, hipotesis yang dapat diajukan dalam penelitian ini adalah:

$\mathrm{H}_{4}$ : Kepercayaan mampu memediasi persepsi risiko terhadap niat menggunakan Mandiri mobile banking.

Berdasarkan kajian pustaka dan hasil studi empiris sebelumnya, maka kerangka konseptual disusun sebagai berikut,

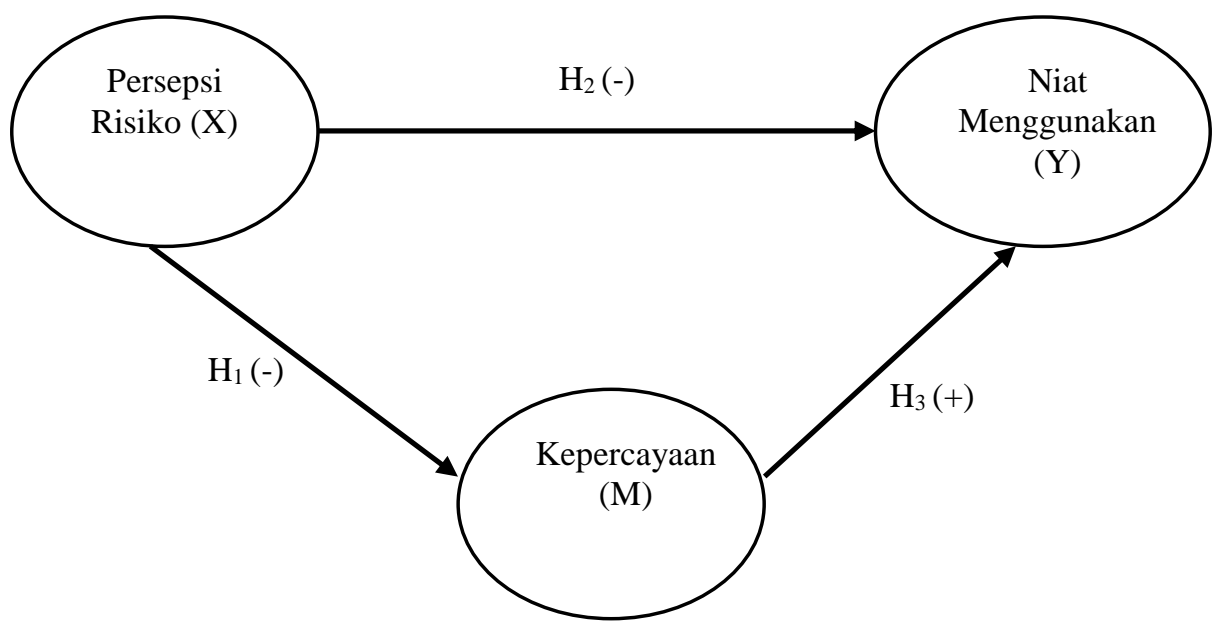

Gambar 1. Kerangka Konseptual

\section{METODE PENELITIAN}

Berdasarkan tingkat eksplanasinya penelitian ini merupakan penelitian asosiatif. Lokasi penelitian dilakukan di Kota Denpasa, kota ini dipilih karena merupakan ibukota serta pusat perdagangan, sehingga mobilitas transaksi lebih tinggi dibandingkan dengan daerah lainnya. 
Pada penelitian ini menggunakan tiga jenis variabel yang dikaji, yaitu variabel bebas berupa persepsi risiko $(\mathrm{X})$. Variabel mediasi berupa kepercayaan (M) dan variabel dependen berupa niat menggunakan (Y). Dalam mengukur ketiga variabel tersebut, digunakan beberapa indikator yang disajikan dalam Tabel 2, sebagai berikut,

Tabel 2.

Indikator Penelitian

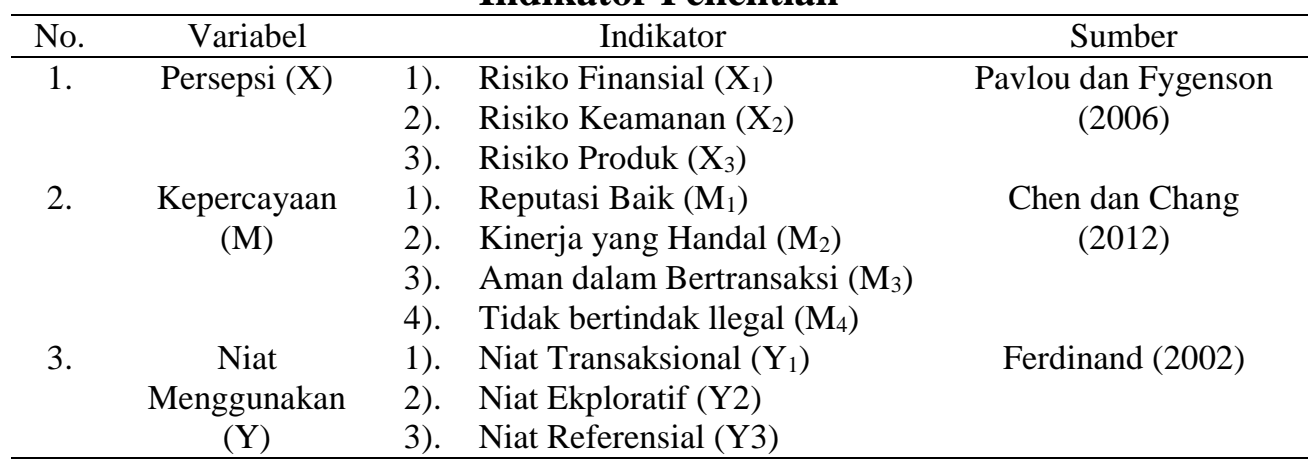

Populasi dalam penelitian ini adalah masyarakat Kota Denpasar yang telah mengetahui tentang Mandiri mobile banking namun belum menggunakannya sebagai salah satu alat untuk melakukan transaksi perbankan yang belum diketahui jumlah pastinya. Menurut Sugiyono (2014:129) mengemukakan ukuran sampel minimum analisis multivariate minimal 10 kali dari jumlah indikator, sehingga jumlah responden yang terlibat adalah 100 responden. Teknik pengambilan sampel yang digunakan dalam penelitian ini adalah Purposive Sampling, sehingga dalam menentukan sampel, diperlukan kriteria tertentu, adapun kriteria yang digunakan adalah pendidikan terakhir minimal SMA/Sederajat, mengetahui Mandiri mobile banking, belum menggunakan Mandiri mobile banking dan berdomisili di Kota Denpasar. 
Ida Ayu Agung Upadianti Jayantari, Peran Kepercayaan Memediasi...

Metode pengumpulan mengunakan teknik penyebaran kuesioner yang secara langsung disebarkan oleh peneliti. Butir-butir pernyataan diukur dengan Skala Likert, dengan rentang penilaian yang dijabarakan pada Tabel 3 sebagai berikut,

Tabel 3.

Alternatif Jawaban Responden

\begin{tabular}{ccc}
\hline Alternatif Jawaban & Kode & Skor \\
\hline Sangat Setuju & SS & 5 \\
Setuju & S & 4 \\
Netral & N & 3 \\
Tidak Setuju & TS & 2 \\
Sangat Tidak Setuju & STS & 1 \\
Sumber: Sugiyono, 2014 & &
\end{tabular}

Dalam penelitian ini digunakan jenis data yang dikelompokkan menurut sifatnya yakni data kualitatif dan data kuantitatif. Data kualitatif berupa pendapat dari para responden mengenai pernyataan dalam kuesioer. Data kuantitatif berupa usia responden, dan data mengenai jumlah pengguna internet oleh APJII. Sumber data yang digunakan pada penelitian ini adalah sumber primer dan sekunder. Sumber data primer adalah responden yang memberikan tanggapan dalam kuesioner mengenai variabel-variabel dalam penelitian. Sumber data sekunder adalah situs Asosisasi Pengguna Jaringan Internet Indonesia (APJII) dan Sloka Institute.

Instumen penelitian berupa kuesioner diuji menggunakan pengujian validitas dan reliabilitas. Pengujian tersebut dilakukan untuk mengetahui apakah kuesioner yang digunakan telah tepat dan berifat konsisten untuk digunakan. Kuesioner dikatakan valid apabila koefisien korelasi $\geq 0,30$. Kuesioner dapat dikatakan reliabel jika nilai Cronbach's Alpha $\geq 0,60$. Teknik analisis data yang digunakan adalah teknik analisis jalur, dan untuk menguji peran mediasi, dilakukan dengan menggunakan Teori Solimun. 


\section{HASIL DAN PEMBAHASAN}

Jumlah responden yang menjadi sampel dalam penelitian ini sebanyak 100 responden. Profil responden diklasifikasikan ke dalam kategori demografi seperti usia, jenis kelamin serta jenjang pendidikan terakhir yang ditempuh. Secara rinci, profil responden disajikan di Tabel 4. sebagai berikut.

Tabel 4.

Profil Responden

\begin{tabular}{|c|c|c|c|c|}
\hline No. & Variabel & Klasifikasi & $\begin{array}{l}\text { Jumlah } \\
\text { (Orang) }\end{array}$ & $\begin{array}{c}\text { Persentase } \\
(\%)\end{array}$ \\
\hline \multirow[t]{5}{*}{1.} & Usia & $18-22$ tahun & 67 & 67,0 \\
\hline & & $23-27$ tahun & 12 & 12,0 \\
\hline & & $28-32$ tahun & 15 & 15,0 \\
\hline & & Diatas 32 tahun & 6 & 6,0 \\
\hline & & Jumlah & 100 & 100,0 \\
\hline \multirow[t]{3}{*}{2.} & Jenis & Perempuan & 69 & 69,0 \\
\hline & Kelamin & Laki-Laki & 31 & 31,0 \\
\hline & & Jumlah & 100 & 100,0 \\
\hline \multirow[t]{3}{*}{3.} & Jenjang & SMA/SMK Sederajat & 65 & 65,0 \\
\hline & Pendidikan & Perguruan Tinggi & 35 & 35,0 \\
\hline & & Jumlah & 100 & 100,0 \\
\hline
\end{tabular}

Dari Tabel 4. diketahui bahwa pada variabel klasifikasi usia didominasi oleh responden yang berusia 18 - 22 tahun sebesar $67 \%$, secara keseluruhan rata rata usia responden adalah 23 tahun. Untuk jenis kelamin, responden didominasi oleh perempuan yang memiliki persentase sebesar 69\%. Sementara itu, di klasifikasi jenjang pendidikan sebanyak $65 \%$ responden berpendidikan minimal tamat SMA/SMK sederajat, sedangkan sisanya sebanyak 35\% responden minimal lulusan perguruan tinggi.

Indikator pada masing - masing variabel diuji menggunakan uji validitas dan reliabilitas. Hasil daripada masing - masing pengujian tersebut disajikan dalam Tabel 5, sebagai berikut. 
Ida Ayu Agung Upadianti Jayantari, Peran Kepercayaan Memediasi...

Tabel 5.

Hasil Uji Validitas dan Reliabilitas

\begin{tabular}{cclcc}
\hline No. & Variabel & \multicolumn{1}{c}{ Indikator } & $\begin{array}{c}\text { Koefisien } \\
\text { Validitas }\end{array}$ & $\begin{array}{c}\text { Koefisien } \\
\text { Reliabilitas }\end{array}$ \\
\hline 1. & Persepsi & Risiko finansial & 0,919 & \\
& Risiko & Risiko keamanan & 0,908 & 0,875 \\
& & Risiko produk & 0,862 & \\
2. & Kepercayaan & Reputasi baik & 0,820 & \\
& & Kinerja handal & 0,869 & 0,838 \\
& & Aman dalam bertransaksi & 0,830 & \\
\multirow{2}{*}{3.} & Tidak bertindak illegal & 0,703 & \\
& Niat & Niat transaksional & 0,902 & \multirow{2}{*}{0,846} \\
& Menggunakan & Niat ekploratif & 0,886 & \\
& & Niat referensial & 0,873 & \\
\hline
\end{tabular}

Sumber: Data diolah, 2017

Data dari Tabel 5. dapat diketahui bahwa masing - masing indikator memiliki koefisien valitas lebih besar dari pada 0,3 dan koefisien reliabilitas lebih besar dari 0,6. Dapat disimpulkan bahwa indikator yang digunakan untuk mengukur masing - masing variabel telah tepat untuk digunakan dan bersifat konsisten.

Deskripsi dari masing - masing variabel dapat diketahui melalui rata - rata skor jawaban dari kuesioner. Rata - rata skor jawaban responden pada kuesioner dikelompokkan kedalam 5 kelas interval dengan keterangan seperti disajikan dalam Tabel 6. Sebagai berikut,

Tabel 6. Rentang Penlilaian Jawaban Responden

\begin{tabular}{ccc}
\hline No. & Rentang & Kriteria \\
\hline 1. & $1,00-1,79$ & Sangat Tidak Baik \\
2. & $1,80-2,59$ & Tidak Baik \\
3. & $2,60-3,39$ & Cukup Baik \\
4. & $3,40-4,19$ & Baik \\
5. & $4,20-5,00$ & Sangat Baik \\
\hline \multicolumn{2}{l}{ Sumber : Wirawam, 2002} &
\end{tabular}

Persepsi risiko sebagai variabel bebas diukur dengan menggunakan 3 indikator. Deskripsi jawaban responden mengenai variabel persepsi risiko, kepercayaan dan niat menggunakan disajikan pada Tabel 7. sebagai berikut. 
Tabel 7.

Deskripsi Jawaban Responden

\begin{tabular}{clcccccc}
\hline \multirow{2}{*}{ Variabel } & \multicolumn{1}{c}{ Indikator } & \multicolumn{5}{c}{ Distribusi Jawaban (\%) } & Rata-Rata \\
& & $\mathbf{1}$ & $\mathbf{2}$ & $\mathbf{3}$ & $\mathbf{4}$ & $\mathbf{5}$ & Skor \\
\hline Persepsi & Risiko Finansial (X1) & 0 & 0 & 31 & 48 & 21 & 3,90 \\
Risiko & Risiko Kemanan (X2) & 0 & 2 & 24 & 46 & 28 & 4,00 \\
& Risiko Produk (X3) & 0 & 1 & 20 & 51 & 28 & 4,06 \\
& & & & & & Total & $\mathbf{3 , 9 9}$ \\
Kepercayaan & Reputasi Baik (M1) & 0 & 0 & 17 & 53 & 30 & 4,13 \\
& Kinerja Handal (M2) & 0 & 0 & 13 & 53 & 34 & 4,21 \\
& Aman Dalam Bertransaksi (M3) & 0 & 0 & 21 & 46 & 33 & 4,12 \\
& Tidak Bertindak Illegal (M4) & 0 & 0 & 16 & 58 & 26 & 4,10 \\
& & & & & & Total & $\mathbf{4 , 1 4}$ \\
Niat & Niat Transaksional (Y1) & 0 & 0 & 17 & 57 & 26 & 4,09 \\
& Niat Eksploratif (Y2) & 0 & 0 & 16 & 53 & 31 & 4,15 \\
& Niat Referensial (Y3) & 0 & 0 & 27 & 39 & 34 & 4,07 \\
& & & & & & Total & $\mathbf{4 , 1 0}$ \\
\hline
\end{tabular}

Sumber : Data diolah, 2017

Hasil dari Tabel 7. menunjukan bahwa variabel persepsi risiko memiliki skor rata rata sebesar 3,99. Responden memiliki penilaian yang cukup baik mengenai produk Mandiri mobile banking. Indikator risiko produk memiliki skor rata-rata tertinggi. Sebanyak $51 \%$ responden setuju dan $28 \%$ responden sangat setuju bahwa Mandiri mobile banking merupakan produk yang dapat diandalkan dalam bertransaksi. Penilaian responden mengenai variabel kepercayaan memiliki skor rata rata sebesar 4,14 , hasil itu termasuk kategori baik. Skor rata rata tertinggi dimiliki oleh indikator kinerja handal. Sebesar 53\% responden setuju dan $34 \%$ responden sangat setuju bahwa Mandiri mobile banking memiliki kinerja baik. Penilaian responden mengenai variabel niat menggunakan memiliki rata rata skor sebesar 4,10, hasil tersebut masuk dalam kategori baik. Secara keseluruhan, responden memiliki penilaian yang baik terhadap niat mereka menggunakan Mandiri mobile banking. Skor tertinggi dimiliki variabel niat eksploratif. Sebanyak $53 \%$ responden sangat setuju dan $31 \%$ responden setuju untuk mengetahui lebih dalam mengenai produk Mandiri mobile banking. 
Tabel 8.

Hasil Analisis Jalur Persamaan Regresi 1

\begin{tabular}{llccccc}
\hline \multirow{2}{*}{ Model } & \multicolumn{2}{c}{$\begin{array}{c}\text { Unstandardized } \\
\text { Coefficient }\end{array}$} & $\begin{array}{c}\text { Standardized } \\
\text { Coefficient }\end{array}$ & t & sig \\
\cline { 2 - 5 } & \multicolumn{2}{c}{ B } & Std.Error & Beta & & \\
\hline $1 . \quad$ (Constant) & 18,670 & 1,021 & & 18,294 & 0,000 \\
& Persepsi Risiko & $-0,528$ & 0,084 & $-0,534$ & $-6,258$ & 0,000 \\
\hline R1 & $: 0,285$ & & & & & \\
F statistik $\quad: 39,158$ & & & & & \\
Sig F & $: 0,000$ & & & & & \\
Sumber : Data diolah, 2017 & & & & &
\end{tabular}

Dari tabel diatas, maka persamaan struktural untuk hipotesis 1 dapat disusun sebagai berikut :

$\mathrm{M}=-0,534+\varepsilon_{1}$

Hasil pada Tabel 8 menunjukan bahwa nilai pengaruh persepsi riko terhadap kepercayaan memiliki koefisien $\beta_{1}=-0,534$ dan $\rho$ value $=0,000$. Nilai koefisien $\beta_{1}>0$ dan nilai $\rho$ value $\leq 0,05$, sehingga $\mathbf{H}_{1}$ diterima dan $\mathrm{H}_{0}$ ditolak. Dapat disimpulkan bahwa persepsi risiko berpengaruh negatif dan signifikan terhadap kepercayaan.

Hasil pengolahan data untuk persamaan regresi 2 disajikan pada Tabel 9. sebagai berikut.

Tabel 9.

Hasil Analisis Jalur Pertsamaan Regresi 2

\begin{tabular}{|c|c|c|c|c|c|c|}
\hline \multirow{2}{*}{\multicolumn{2}{|c|}{ Model }} & \multicolumn{2}{|c|}{$\begin{array}{c}\text { Unstandardized } \\
\text { Coefficient }\end{array}$} & \multirow{2}{*}{$\begin{array}{c}\begin{array}{c}\text { Standardized } \\
\text { Coefficient }\end{array} \\
\text { Beta }\end{array}$} & \multirow[t]{2}{*}{$\mathbf{t}$} & \multirow[t]{2}{*}{ Sig } \\
\hline & & B & Std.Error & & & \\
\hline (Cons & & 6,785 & 1,576 & & 4,306 & 0,000 \\
\hline Perse & Risiko & $-0,207$ & 0,073 & $-0,211$ & $-2,821$ & 0,006 \\
\hline Keper & aan & 0,647 & 0,074 & 0,651 & 8,717 & 0,000 \\
\hline $\mathrm{R} 2^{2}$ & $: 0,614$ & & & & & \\
\hline F Statistik & : 77,130 & & & & & \\
\hline Sig F & $: 0,000$ & & & & & \\
\hline
\end{tabular}

Dari tabel diatas, maka persamaan struktural untuk hipotesis 2 dan 3 dapat disusun sebagai berikut.

$$
\mathrm{Y}=-0,211+0,651+\varepsilon_{2}
$$


Keterangan :

$$
\begin{aligned}
& X=\text { Persepsi Risiko } \\
& M=\text { Kepercayaan } \\
& Y=\text { Niat Menggunakan } \\
& B=\text { Koefisien Regresi } \\
& E=\text { error }
\end{aligned}
$$

Hasil pada Tabel 9. menunjukan bahwa nilai pengaruh persepsi risiko terhadap niat menggunakan memiliki koefisien $\beta_{2}=-0,211$ dan $\rho$ value $=0,006$. Nilai koefisien $\beta_{2}>0$ dan nilai $\rho$ value $\leq 0,05$, sehingga $\mathbf{H}_{2}$ diterima dan $\mathrm{H}_{0}$ ditolak. Dapat disimpulkan bahwa persepsi risiko berpengaruh negatif dan signifikan terhadap niat menggunakan. Hasil pada Tabel 9. menunjukan bahwa nilai pengaruh kepercayaan terhadap niat menggunakan memiliki koefisien $\beta_{2}=$ 0,651 dan $\rho$ value $=0,000$. Nilai koefisien $\beta_{3}>0$ dan nilai $\rho$ value $\leq 0,05$, sehingga $\mathbf{H}_{3}$ diterima dan $\mathrm{H}_{0}$ ditolak. Dapat disimpulkan bahwa kepercayaan berpengaruh positif dan signifikan terhadap niat menggunakan.

Berdasarkan persamaan regresi 1 dan 2, maka nilai error untuk masing masing persamaan dihitung sebagai berikut

$$
\begin{array}{ll}
\varepsilon_{1} & =\sqrt{1-R_{1}^{2}}=\sqrt{1-0,285}=0,715 \ldots \\
\varepsilon_{2} & =\sqrt{1-R_{2}^{2}}=\sqrt{1-0,614}=0,386 .
\end{array}
$$

Dari nilai $\varepsilon_{1}$ dan $\varepsilon_{2}$ yang telah diketahui maka koefisien determinasi total dapat dihitung sebagai berikut:

$$
\begin{aligned}
\mathrm{R}^{2} \mathrm{~m} & =1-\left(\mathrm{P} \varepsilon_{1}\right)^{2}\left(\mathrm{P} \varepsilon_{2}\right)^{2} \ldots \ldots \ldots \ldots \ldots \\
& =1-(0,715)^{2}(0,386)^{2}=0,925
\end{aligned}
$$


Ida Ayu Agung Upadianti Jayantari, Peran Kepercayaan Memediasi...

Sebesar 92,5\% variabel niat menggunakan dipengaruhi oleh persepsi risiko dan kepercayaan, serta efek dari kepercayaan sebagai variabel mediasi hubungan persepsi risiko dengan niat menggunakan. Sedangkan sisanya sebanyak $7,5 \%$ dijelaskan oleh variabel lain yang tidak dimasukan kedalam model.

Hasil pada Tabel 8 dan Tabel 9 menunjukan nilai koefisien sig.F adalah 0,000. Nilai koefisien ini lebih kecil dibandingkan 0,05 sehingga dapat disimpulkan bahwa model persamaan struktural 1 dan 2 telah memenuhi syarat Goodness of Fit melalui uji F. Dari hasil perhitungan koefisien regresi, nilai error dan determinasi total, maka disusun diagram model analisis jalur seperti pada Gambar 2. sebagai berikut,

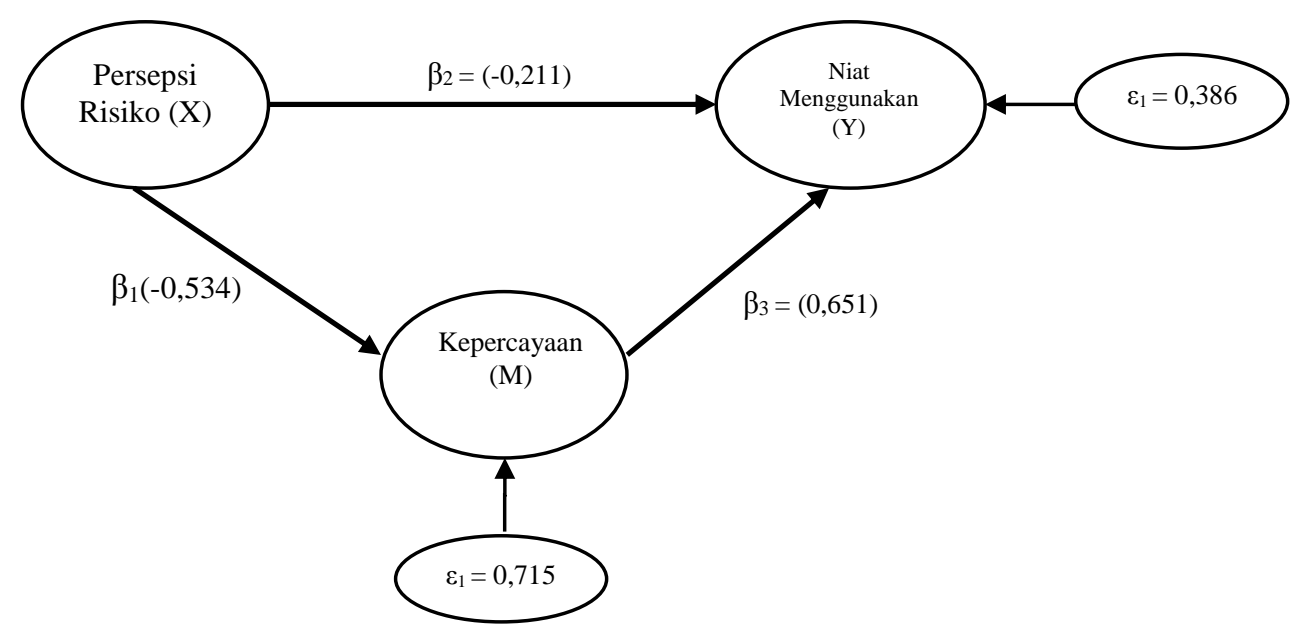

Gambar 2. Validasi Model Diagram Jalur

Menurut Teori Solimun serta hasil yang didapatkan dari model tanpa melibatkan variabel mediasi dan Gambar 2. validasi model diagram jalur akhir maka memenuhi kriteria yaitu hasil analisis koefesien jalur $\beta_{2}^{\prime}$ dengan signifikansi sebesar $0,006<0,05$ dan beta sebesar 0,112 maka, persepsi risiko berpengaruh signifikan terhadap niat menggunakan. Hasil dari $\beta_{1}$ dan $\beta_{3}$ berpengaruh signifikan dengan hasil tingkat signifikansi $\beta_{1}$ sebesar 0,000 dan beta 
sebesar $-0,534$ serta hasil tingkat signifikansi $\beta_{3}$ sebesar 0,000 dan beta sebesar 0,651. Tingkat signifikansi $\beta_{2}$ berpengaruh signifikan sebesar 0,006 dengan beta sebesar -0,211. Hasil koefesien jalur $\beta_{2}$ adalah -0,211 lebih kecil (turun) dari $\beta_{2}{ }^{\prime}$ yaitu sebesar 0,112 maka variabel kepercayaan adalah sebagai variabel mediasi sebagian (partial mediation).

Pengujian hipotesis terhadap hubungan antara variabel persepsi risiko dan kepercayaan menunjukan hasil diterima, yaitu persepsi risiko berpengaruh negatif dan signifikan terhadap kepercayaan. Ini artinya, semakin tinggi risiko, maka semakin rendah kepercayaan pengguna untuk menggunakan Mandiri mobile banking. Hasil dari penelitian terhadap responden yang disajikan dalam deskripsi variabel penelitian menunjukan bahwa penilaian reponden terhadap persepsi risiko berada dalam kategori cukup baik. Responden merasa risiko-risiko yang mungkin ditimbulkan dalam penggunaan Mandiri mobile banking terutama risiko finansial membuat kepercayaan mereka terhadap produk tersebut menurun. Hasil penelitian ini mendukung sejumlah penelitian penelitian serupa terdahulu seperti Nazar dan Syahran. (2008),Suhir (2014), (Eastlick et al., 2006). dan Firdayanti (2012) yang menunjukan bahwa persepsi risiko berpengaruh negatif dan signifikan terhadap kepercayaan.

Pengujian hipotesis terhadap hubungan antara variabel persepsi risiko dan niat menggunakan menunjukan hasil diterima, yaitu persepsi risiko berpengaruh negatif dan signifikan terhadap niat menggunakan. Ini artinya, semakin tinggi risiko, maka semakin rendah niat menggunakan pengguna dalam bertransaksi melalui Mandiri mobile banking. Hasil dari penelitian terhadap responden yang 
Ida Ayu Agung Upadianti Jayantari, Peran Kepercayaan Memediasi...

disajikan dalam deskripsi variabel penelitian menunjukan bahwa penilaian reponden terhadap persepsi risiko dengan niat menggunakan berada dalam kategori baik. Responden merasa persepsi-persepsi risiko yang mungkin ditimbulkan saat bertransaksi melalui Mandiri mobile banking dapat menurunkan niat mereka untuk menggunakan produk tersebut. Hasil penelitian ini mendukung sejumlah penelitian-penelitian serupa terdahulu seperti Dewi (2016), Kim et al.,(2008) serta Martinayanti (2016) yang menyebutkan bahwa persepsi risiko berpengaruh negatif dan signifikan terhadap niat menggunakan.

Pengujian hipotesis terhadap hubungan antara variabel kepercayaan dan niat menggunakan menunjukan hasil diterima, yaitu kepercayaan berpengaruh positif dan signifikan terhadap niat menggunakan. Ini artinya, semakin tinggi kepercayaan, maka semakin tinggi pula niat menggunakanMandiri mobile banking dalam bertransaksi. Hasil dari penelitian terhadap responden yang disajikan dalam deskripsi variabel penelitian menunjukan bahwa penilaian reponden terhadap kepercayaan dengan niat menggunakan berada dalam kategori baik. Responden yakin bahwa kepercayaan mampu meningkatkan niat dalam menggunakan mandiri mobile banking sebagai alat transaksi. Hasil penelitian ini mendukung sejumlah penelitian penelitian serupa terdahulu seperti Dewi (2016), Kim et al.,(2008) serta Martinayanti (2016) yang menyebutkan bahwa persepsi risiko berpengaruh negatif dan signkifikan terhadap niat menggunakan

Variabel yang terkait dalam penelitian ini telah diuji dan terbukti berpengaruh positif dan signifikan. Pengaruh yang ingin dibuktikan dalam penelitian ini adalah peran kepercayaan dalam memediasi pengaruh persepsi 
risiko terhadap niat menggunakan. Hasil sebelum adanya variabel kepercayaan sebagai mediasi yaitu -0,211namun dengan adanya variabel kepercayaan sebagai variabel mediasi membuat pengaruh total dari penelitian ini semakin meningkat yaitu mencapai 0,112 . Hasil tersebut menunjukkan bahwa kepercayaan memediasi pengaruh persepsi risiko terhadap niat menggunakan secara parsial. Hasil ini juga didukung dengan adanya teori Solimun yang membuktikan bahwa koefesien jalur $\beta_{2}$ sebesar -0,211 lebih kecil (turun) dari $\beta_{2}^{\prime}$ yaitu sebesar 0,112 maka variabel kepercayaan adalah sebagai variabel mediasi sebagian (partial mediation). Hasil penelitian ini mendukung penelitian yang dilakukan oleh Ling et al.,(2011), Murwatiningsih dkk.(2013) serta Martinayanti (2016) yang menyimpulkan bahwa kepercayaan mampu memediasi persepsi risiko terhadap niat menggunakan.

Implikasi penelitia ini menekankan manfaat nyata dari hasil penelitian untuk meningkatkan kepercayaan pelanggan terhadap niat menggunakan Mandiri mobile banking sebagai alat transaksi serta menurunkan risiko risiko yang mungkin ditimbulkan dari produk tersebut. Berikut beberapa implikasi dari penelitian yang diperoleh. Pertama, persepsi risiko berpengaruh terhadap niat menggunakan, maka dari itu, perusahaan terkait harus mampu menurunkan risiko risiko yang mungkin ditimbulkan saat akan menggunakan Mandiri mobile banking. Terutama untuk risiko finansial, karena risiko tersebut mendapat skor tertingi pada hasil kuisioner. Sehingga, dapat dikatakan bahwa semakin tinggi persepsi risiko yang dimiliki, maka semakin rendah pula niat mengggunakan produk Mandiri mobile banking. 
Ida Ayu Agung Upadianti Jayantari, Peran Kepercayaan Memediasi...

Kedua, kepercayaan merupakan suatu hal yang dapat meningkatkan niat menggunakan suatu produk. Dengan adanya kepercayaan yang tinggi, maka niat menggunakan juga akan meningkat. Hal ini yang harus diperhatikan oleh perusahaan terkait agar dapat melakukan usaha usaha yang dapat meningkatkan kepercayaan para calon pengguna seperti peningkatan dalam kualitas produk dan pelayanan. Berdasarkan kuisioner yang telah disebar, dapat dilihat indikator kinerja handal mendapat skor yang paling tinggi. Ini berarti, kehandalan kinerja sangat berpengaruh terhadaap meningkatnya kepercayaan akan suatu produk.

Terakhir, dengan adanya kepercayaan yang tinggi, maka berbanding lurus dengan niat menggunakan yang tinggi juga. Hal ini dibuktikan berdasarkan hasil kuisioner yang disebar yaitu indikator niat eksploratif mendapat skor tertinggi. Artinya, dengan meningkatnya kepercayaan, maka niat seseorang untuk mengetahui dan mencari informasi tentang suatu produk juga akan bertambah. Hal ini nantinya akan dapat berdampak kepada penggunaan produk yang nyata karena calon pengguna sudah menunjukan ketertarikannya terhadap produk tersebut.

\section{SIMPULAN DAN SARAN}

Berdasarkan hasil pembahasan diatas, maka kesimpulan dari penelitian ini adalah persepsi risiko berpengaruh negatif dan signifikan terhadap niat menggunakan Mandiri mobile banking. Hasil tersebut dapat diartikan bahwa semakin tinggi persepsi risiko yang dimiliki oleh calon pengguna maka semakin rendah niat menggunakan produk yang mereka miliki. Persepsi risiko berpengaruh negatif dan signifikan terhadap kepercayaan. Hasil yang diperoleh memiliki arti 
bahwa semakin tinggi persepsi risiko yang ada maka semakin rendah kepercayaan dari calon pengguna.

Kepercayaan berpengaruh positif dan signifikan terhadap niat menggunakan Mandiri mobile banking. Hasil yang di dapat memiliki arti bahwa semakin tinggi kepercayaan konsumen maka semakin tinggi juga niat menggunakan yang mereka miliki. Peran kepercayaan secara signifikan mampu memediasi persepsi risiko dan niat menggunakan Mandiri mobile banking. Jadi dapat disimpulkan bahwa niat menggunakan akan menjadi semakin tinggi jika kepercayaan yang dimiliki mampu menurunkan persepsi persepsi risiko yang mungkin ditimbulkan. Berdasarkan kesimpulan yang telah dipaparkan, beberapa saran yang dapat diberikan untuk perusahaan maupun untuk penelitian selanjutnya yang serupa adalah bagi perusahaan, hasil dari penelitian ini dapat dijadikan pertimbangan untuk dapat meningkatkan kepercayaan calon pengguna serta menurunkan persepsi risiko yang ada di benak mereka, terutama risiko finansial serta meningkatkan niat eksploratif calon pengguna. Hasil penelitian ini juga membuktikan bahwa kepercayaan berbanding lurus dengan niat menggunakan suatu produk sehingga, perusahaan harus memperhatikan aspek aspek yang dapat membangun kepercayaan tersebut.

Bagi peneliti selanjutnya, diharapkan dapat menambah variabel lain yang mempengaruhi niat menggunakan suatu produk. Selain itu dapat juga menambah jumlah responden dan memperluas ruang lingkup penelitian agar hasil yang didapat lebih akurat. 
Ida Ayu Agung Upadianti Jayantari, Peran Kepercayaan Memediasi...

\section{REFERENSI}

Afzal, H.,Khan, Muhammad Aslam,Rehman, Kashif Ali, Imran, and Wajahat, Sobia. 2010. Consumer's Trust in the Brand: Can it Be Built through Brand Reputation, Brand Competence and Brand Predictability. International Business Research, 3(1), pp:43-51.

Ago, G.,Suharno.,Mintarti, S., dan Hariyadi, S. 2015. Effect of Product Quality Perception, Trust, and Kepercayaan on Generic Drug Buying Decision and Consumer Satisfaction of Hospital Patients in East Kalimantan. European Journal of Business and Management, 7 (14), pp:50-68.

Anwar,Rosian dan Wijaya Adidarma. 2016. Pengaruh Kepercayaan dan Resiko Pada Minat Belanja Online. Jurnal Manajemen dan Bisnis Sriwijaya, 4(2),hal:165-166

Arslan, Geçti dan Zengin. 2013. Examining Perceived Risk and Its Influence on Attitudes: A Study on Private Label Consumers in Turkey. Asian Social Science Journal, 9(4), pp:158-166

Asosiasi Pengguna Jaringan Internet. 2017. Data Statistik Pengguna Internet di Indonesia. https://apjii.or.id/. Diakses pada tanggal 20 Maret 2017

Benaditta, Lilyana Veronica. 2012. Pengaruh Persepsi Nilai dan Resiko Terhadap Niat Beli : Penguji Kepercayaan Sebagai Variabel Pemediasi. Jurnal Manajemen Universitas Atma Jaya Yogyakarta, 1(1), hal.:1-10

Chen, Hui. 2012. The Influence of Perceived Value and Trust on Online Buying Intention. Journal of Computers, 7(7), pp:1655-1662.

Chen, Y.S., dan Chang, C.H. (2012). Enhance Green Purchas Intentions ,The Roles Of Green Perceived Value, Green Perceived Risk, and Green Trust. Journal of Management Decision, 50(3), pp:502-520.

Chong, B.,Yang, Z., dan Wong, M. 2003. Asymmetrical Impact of Trustworthiness Attributes Trust, Perceived Value and Niat menggunakan: A Conceptual Framework for Cross-cultural Study on Consumer Perception of Online. In Proceedings of the $5^{\text {th }}$ international conference on electronic commerce Pittsburgh, Pennsylvania30sept-3 oct 2003. pp:213-219

Dewi, Ni Made Ari Puspita. 2016. Peran Persepsi Kemudahan Penggunaan, Persepsi Manfaat dan Persepsi Risiko Terhadap Niat Menggunakan ECommerce di Kota Denpasar.E-Jurnal Manajemen Universitas Udayana,5(4),hal:2606-2636

Eastlick, M. A., Lotz, S. L. dan Warrington, P. 2006. Understanding Online B-toC Relationships: An Integrated Model of Privacy Concerns, Trust, and Commitment. Journal of Business Research,59(8),pp:877-886. 
Firdayanti, R. 2012. Persepsi Risiko Melakukan E-Commerce dengan Kepercayaan Konsumen dalam Membeli Produk Fashion Online. Journal of Social and Industrial Psychology. 1(1), hal:1-7

Fitriani. 2013. Model Kepercayaan Merek (Trust in Brand) Dikalangan Nasabah Pegadaian Syariah Cabang Banda Aceh. Jurnal Ekonomi Manajemen Dan Bisnis, 1(1), hal:42-55.

Ferdinand, Augusty. 2002. Metode Penelitian Manajemen. Semarang: Badan Penerbit Universitas Diponegoro

Gefen, D., Rao, V.S. dan Tractinsky, N. 2003. The Conceptualization of Trust, Risk and Their Relationship in Electronic Commerce: The Need For Clarification, Proceedings of the 26th Hawai International Conference on System Sciences 6 jan-9 jan 2003. pp:1-10.

Gefen, D dan Straub, D.W. 2004. Consumer Trust in B2C e-Commerce and The Importance of Social Presence: Experiments in e-Products and e-Services . Omega. The International Journal of Management Science, 32 , pp:407 424

Gefen, D dan Straub, D.W. 2005. The Relative Importance of Perceived Ease of Use in IS Adoption: A Study of e-Commerce Adoption. Journal of the association for information system, 1(8), pp:1-30

Ghozali, Imam. 2013. Aplikasi Analisis Multivariate dengan Program IBM SPSS 2.1, Edisi. Ketujuh. Semarang. Badan Penerbit UNDIP.

Gurung, Anil. 2006. Empirical Investigation of the Relationship of Privacy, Security, And Trust with Behavioral Intention to transact in E-Commerce. The University Of Texas at Arlingon,4(1)pp:45-54

Hanafi, M Mamduh. 2009. Manajemen Risiko. Yogyakarta. Rumah Tinggi Ilmu Manajemen YKPN

Hartono, Jogiyanto. 2012. Manajemen Pemasaran. Yogyakarta: BPFE Universitas Gajah Mada.

Hong, I.B., dan Cho, H. 2011. The Impact of Consumer Trust on Attitudinal Loyalty and Niat menggunakans in B2C E-Marketplaces: Intermediary Trust vs. Seller Trust. International Journal of Information Management. 31(5), pp:469-479.

Ichwan. 2014. Peningkatan Transaksi online. www.pajak.go.id. Diakses pada 24 Maret 2017

Jaafar, Siti Nurafifah., Lalp, Pan Ein., dan Mohamed, Mohaini. 2012. Consumers' Perceptions, Attitudes and Niat menggunakan towards Private Label Food 
Ida Ayu Agung Upadianti Jayantari, Peran Kepercayaan Memediasi...

Products in Malaysia. Asian Journal of Business and Management Sciences, 2(8), pp:73-90.

Kamtarin. Milad. 2012. The Effect of Electronic Word of Mouth, Trust and Perceived Value on Behavioral Intention from the Perspective of Consumers. International Journal of Academic Research in Economics and Management Sciences. 1(4), pp:2-11

Kim, D.J., Ferrin, D. L., dan Rao, H. R. 2008. A Trust-Based Consumer Decision-Making Model in Electronic Commerce: The Role of Trust, Perceived Risk, and Their Antecedents. Decision Support Systems Journal, 4(4) , pp:544-564

Kompas. 2017. Pengguna Internet di Indonesia Capai 132 Juta. http://tekno.kompas.com/read/2016/10/24/15064727/2016.pengguna.interne t.di.indonesia.capai.132.juta. Diakses pada tanggal 19 Maret 2017

Laudon, Kenneth C dan Jane P. Laudon. 2007. Sistem Informasi Manajemen. Edisi ke-10. Terjemahan Chriswan Sungkono dan Machmudin Eka P. Jakarta. Salemba Empat.

Ling, Kwek Choon,, Lau Teck Chai, dan Piew, Tan Hoi. 2010. The Effects of Shopping Orientations, Online Trust and Prior Online Purchase Experience toward Customers' Online Niat menggunakan. Canadian Center of Science and Education, 3(3), pp:1-14

Ling, Kwek Choon., Dazmin bin Daud., Piew, Tan Hoi.,dan Kay Hooi Keoy. 2011. Perceived Risk, Perceived Technology, Online Trust for the Online Niat menggunakan in Malaysia International Journal of Academic Research in Business and Social Sciences,International Journal of Business and Management, 6(6), pp:167-182

Mandiri.2017.http://www.bankmandiri.co.id/corporate01/about_awards.asp. Diakses pada tgl 10 Oktober 2017

Martinayanti, Ni Made Putri. 2016. Peran Kepercayaan Dalam Memediasi Persepsi Resiko Terhadap Niat Beli Produk Fashion Via Instagram Di Kota Denpasar. E-jurnal Manajemen Universitas Udayana, 5(4), hal:22-23

Martinez, B. dan Kim, S. 2012. Predicting niat menggunakan for private sale sites. Journal of Fashion Marketing and Management, 16 (3), pp:342-365.

Masoud, E.Y. 2013. The Effect of Perceived Risk on Online Shopping in Jordan. European Journal of Business and Management, 5(6), pp: 76-87

Mayer, R.C., Davis, J. H., dan Schoorman, F.D. 1995. An Integratif Model of Organizational Trust. Academy of Management Review, 20(3), pp:709-734. 
Metro Ethernet Forum (MEF). 2017. Penggunaan Mobile Banking Capai 80\% di Indonesia, Isu Kepercayaan Menjadi Masalah Terbesar. https://dailysocial.id/post/mobile-banking-indonesia. Diakses pada tanggal 20 Maret 2017

Mowen, John C. dan Minor Michael. 2002. Perilaku Konsumen Jilid 1, Jakarta. Erlangga

Murwatiningsih. dan E.P.Apriliani. 2013. Pengaruh Risiko Dan Harga Terhadap Keputusan Pembelian Melalui Kepercayaan Konsumen. Jurnal Dinamika Manajemen, 4(2), hal:184-191.

Nazar dan Syahran. 2008. Pengaruh Privasi, Keamanan, Kepercayaan, dan Pengalaman terhadap Niat untuk Bertransaksi secara Online. Jurnal Manajemen Universitas Gajahmada Yogyakarta, hal:2-60

Novitasari dan Baridwan. 2014. Pengaruh Kepercayaan, Persepsi Resiko, Persepsi Manfaat,dan Persepsi Kontrol Perilaku Terhadap Niat Penggunaan Sistem E-Commerce. JurnalImiah Mahasiswa FEB,3(1),hal:1-21

Nusarika, Luh Alvioita Kusuma. Pengaruh Persepsi Harga,Kepercayaan dan Orientasi Belanja Terhadap Niat Beli Secara Online (Studi PadaProfuk Fashion Online di Denpasar. E-Jurnal Manajemen Universitas Udayana,4(8),hal:1-27

Pavlou, P. 2001. Integrating Trust in Electronic Commerce with the Technology Acceptance Model: Model Development and Validation. Seven Americas Conference on Information Systems, pp:816-822

Pavlou, P. dan Fygenson M. 2006. Understanding and Predicting Electronic Commerce Adoption : An Extension of the Theory of Planned Behavior.Management Information Systems Research Center, University of Minnesota. 30(1), pp:115-143

Pratiwi, Devvy Pisheila, 2012. Pengaruh Persepsi Manfaat,Persepsi Kemudahan dan Pengalaman Terhadap Perilaku Penggunaan Mobile Banking Dengan Dimediasi Niat Menggunakan Mobile Banking Nasabah BCA Di Surabaya, Jurnal Manajemen Sekolah Tinggi Ilmu Ekonomi Perbanas. Surabaya, hal:1-136

Rahayu, Djawato Yuliastuti. 2012. Pengaruh Trust Terhadap Risk Perception, Attitude Toward Online Shopping dan Intention To Shop Online Pada Toko Busana Online di Surabaya. Jurnal Akuntansi Manajemen Bisnis \& Sektor Publik, 8(2), hal: 1-30

Rahyuda, I K., Yasa, I G. W., dan Yuliarmi, N. N. 2004. Metodologi Penelitian. Diktat Kuliah Fakultas Ekonomi. Denpasar: Universitas Udayana 
Ida Ayu Agung Upadianti Jayantari, Peran Kepercayaan Memediasi...

Riduwan dan Kuncoro. 2011. Cara Menggunakan dan Memakai Path Analysis (analisis jalur). Bandung. Alfabeta.

Rizanata, Muhamad Fahmi. 2014. Pengaruh Kepercayaan Pelanggan Terhadap Word Of Mouth, Niat Beli Dan Retensi Pelanggan Gerai Indomaret Di Surabaya. Journal of Business and Banking. 4(1), hal:31-42.

Rong, L., Kim, J.J., dan Park, J.S. 2007. The effects of Internet Shoppers' Trust on Their Purchasing Intention in China. Journal of Sociological Research, 2(1),pp:1-18

Samadi, Mansour dan Ali Yaghoob-Nejadi 2009. A Survey of the Effect of Consumers' Perceived Risk on Niat menggunakan. E-Shopping, Business Intelligence Journal, 2(2), pp: 1-45

Shomad, A.C., dan Purnomosidhi, B. 2013. Pengaruh Kepercayaan, Persepsi Kegunaan, Persepsi Kemudahan, dan Persepsi Risiko Terhadap Perilaku Penggunaan E- Commerce. Jurnal Ilmiah Mahasiswa FEB Universitas Brawijaya, 1(2), hal:1-20.

Suhir, Suyadi dan Riyadi .2014. Pengaruh Persepsi Risiko,Kemudahan Dan Manfaat Terhadap Keputusan Pembelian Secara Online (Survei Terhadap Pengguna Situs Website (www.Kaskus.co.id). Jurnal Administrasi Bisnis (JAB),8(1), hal:9-10

Sujana,Kadek Ciptadi. 2016. Peran Kepercayaan Dalam Memediasi Pengaruh Kualitas Situs Terhadap Niat Konsumen Untuk Berbelanja Di Situs Zalora. E-Jurnal Manajemen Universitas Udayana,5(1),hal:595-622

Siagian, Hotlan., dan Cahyono, Edwin. 2014. Analisis Website Quality, Trust, dan Loyalty Pelanggan Online Shop. Jurnal Manajemen Pemasaran Fakultas Ekonomi Universitas Kristen Petra, 8(2), hal:55-61.

Soesatyo, N., dan Rumambi, L.J. 2013. Analisa Credibility Celebrity Endorser Model : Sikap Audience Terhadap Iklan Dan Merek Serta Pengaruhnya Pada Minat Beli “ Top Coffee”. Jurnal Manajemen Pemasaran. 1(2), hal:112

Solimun., Adji Achmad Rinaldo Fernandes, dan Nurjannah. 2017. Metode Statistika Multivariat Pemodelan Persamaan Struktural (SEM) Pendekatan WarpPLS. Malang: UB Press.

Stephanie,E., Rumambi, L.J., dan Yohanes Sondang Kunto, Y.S. 2013. Analisa Pengaruh Rio Dewanto Dan Donita Sebagai Celebrity Endorser Terhadap Minat Beli Produk Axe Anarchy Dengan Daya Tarik Iklan Dan Efek Iklan Sebagai Variabel Intervening. Jurnal Strategi Pemasaran, 1(2), hal: 1-9 
Sugiyono. 2014. Metode Penelitian Bisnis. Bandung. Alfabeta

Suprapti, N.W.S. 2010. Perilaku Konsumen Pemahaman Dasar dan Aplikasinya Dalam Strategi Pemasaran. Denpasar: Udayana University Press.

Swastha,Basu dan Irawan. 2005 Manajemen Pemasaran Modern. Yogyakarta: Liberty

Tampubolon, P. Manahan, 2004, Manajemen Operasional, edisi pertama. Jakarta: Ghalia

Thakur, Rakhi dan Srivastaya, Mala. 2012. Customer Usage Intention of Mobile Commerce in India. Journal of Indian Business Research, 5(1), pp: 53-72

Utama, Made Suyana. 2016. Aplikasi Analisis Kuantitatif. Denpasar: Sastra Utama.

Vebrika ST, Helza. 2007. Pengaruh Kualitas Jasa Internet Banking Terhadap Kepuasan Konsumen. Jurnal Manajemen Universitas Gunadarma, hal:1-18

Vivanews. 2017. Siapa Bank Terbaik Menurut Survei. http://www.viva.co.id/bisnis/227560-siapa-bank-terbaik-menurut-survey. Diakses pada tgl 10 Oktober 2017

Warmanto, Frans \& Thenu, Noviant Handhika. 2008. Analisis Hubungan Antara Sikap, Norma Subjektif, Dan Kontrol Keperilakuan Yang Dirasakan Terhadap Perilaku Berbagi Pengetahuan Manajer: Studi Empiris Pada Perusahaan Di Wilayah Jakarta. Jurnal Fakultas Ekonomi Universitas Pelita Harapan. hal:1-34

Wikipedia. 2017. Sejaran E-Banking di Indonesia.https://id. wikibooks.org/wiki/Sejarah_Internet_Indonesia/e-banking. Diakses pada 20 Oktober 2017

Wirawan, Nata. 2002. Cara Mudah Memahami Statistik 1 (Statistik Deskripstif) Edisi 1. Denpasar : Keramat Emas

Wu, S.I, dan Chen, Y.J. 2014. The Impact of Green Marketing and Perceived Innovation on Niat menggunakan for Green Products. International Journal of Marketing Studies, 6(5), pp:1-2 